Short Communication

\title{
Effect of Intensive and Semi-intensive Feeding System on Productive and Reproductive Performances of Native Sheep
}

\author{
N. Sultana ${ }^{1}$, M. N. Hasan ${ }^{1}$, A. Iqbal ${ }^{2 *}$, M. Ershaduzzaman ${ }^{1}$, M. A. I. Talukdar ${ }^{1}$, and S. Dey ${ }^{2}$ \\ ${ }^{1}$ Goat and Sheep Production Research Division, Bangladesh Livestock Research Institute (BLRI), \\ Savar, Dhaka \\ ${ }^{2}$ Department of Genetic Engineering and Biotechnology, Shahjalal University of Science and \\ Technology, Sylhet, Bangladesh
}

Received 18 February 2011, accepted in final revised form 8 July 2011

\begin{abstract}
The experiment was conducted with forty four pre-pubertal stages female lambs of $12.5 \pm 2.5$ $\mathrm{kg}$ average live weight and $7.5 \pm 0.5$ months of average age. Animals were equally and randomly allocated into two feeding groups, intensive and semi-intensive feeding systems with 22 animals in each group. Under intensive system, animals were fed concentrate mixture (15.0\% crude protein (CP); 11 MJ metabolizable energy (ME)/kg dry matter (DM)) at the rate of $1.5 \%$ of live weight with ad libitum green grass from May to November and supplied urea molasses straw (UMS) in place of green grass from December to April. There were no significant differences $(p>0.05)$ in service per conception, litter size, lambing interval, gestation length, service period, birth weight and weaning weight between intensive and semi-intensive feeding system. Reproductive traits and productive traits were not affected by feeding system. Conception rate was higher (98.0\%) in semi-intensive system than intensive system (83.0\%). On the other hand lamb survivability was higher in intensive system than in semi-intensive system. The semi-intensive feeding system is found to be better to rear sheep for commercial purpose compared to intensive feeding system.
\end{abstract}

Keywords: Feeding system; Productive; Reproductive; Native sheep.

(c) 2011 JSR Publications. ISSN: 2070-0237 (Print); 2070-0245 (Online). All rights reserved.

doi:10.3329/jsr.v3i3.7129 J. Sci. Res. 3 (3), 692-698 (2011)

\section{Introduction}

There are about 2.78 million sheep in Bangladesh [1]. They are mostly reared by family members under zero input in char or coastal area and also in plane land. In adequate amount and poor quality feed resources are the main constraints to sheep production under the existing systems. Consequently, poor feeding regime is affecting on the genetic potentiality of native sheep and breed improvement programmes. Sheep can easily be

*Corresponding author: asif_abg@yahoo.com 
maintained under rural conditions because of their ability to adapt to harsh environment, poor management and feeding practices. In our country, goats and sheep are mainly kept by the poor farmers and distressed women in extensive system under ranged condition without any supplementation. This system of production causes reduced growth rate and poor reproductive performance, which in turn results in severe economic losses. Previous studies [2, 3] have reflected the importance of concentrate supplementation on growth and productivity of goats and sheep. They also that grazing alone may not be sufficient for optimizing live weight gain and wool production. There was no investigation about which type of feeding system is better for productive and reproductive performances of native sheep in Bangladesh. Therefore, this study was conducted to determine the effect of intensive and semi-intensive feeding system on productive and reproductive performances of native sheep.

\section{Materials and Method}

Forty four pre-pubertal stages female lamb of about average $12.5 \pm 2.5 \mathrm{~kg}$ live weight and about 7.5 \pm 0.5 months of age were randomly selected from BLRI sheep farm. All animals were dewormed and injected with $1.5 \mathrm{ml}$ of $\mathrm{AD}_{3} \mathrm{E}$ at the start of the trial. Animals were equally and randomly allocated into intensive and semi-intensive feeding system. Under intensive system, animals were fed concentrate ration (15.0\% CP; $11 \mathrm{MJ} \mathrm{ME} / \mathrm{kg} \mathrm{DM}$ ) at the rate of $1.5 \%$ of live weight and were not allowed any grazing. In semi-intensive system, in addition to daily grazing 8 hours, animal were fed concentrate ration at the rate of $1.5 \%$ of the live weight. The grazing animals were offered to clean drinking water twice daily, in the morning and afternoon on return from grazing area. After grazing, the ewes were housed during night in a permanent wood floor house. The trial was conducted from the month of May to November 2008. In both feeding systems, lambs were kept with their mother for two month. In-semi intensive system, after one month lambs were stayed with their mother except grazing time. The entire 44 ewes were mated as per approved plan of breeding at Sheep Farm at BLRI. Reproductive traits viz. service(s) per conception, gestation length, litter size and birth weight were recorded. Heat was detected from the physical signs of heat which was confirmed with a treasured buck. Body weights of lambs from all experimental animals were recorded each week. Milk yield was recorded after lambing up to two weeks. Milk production was determined by lamb suckling method. Weekly body weight was recorded for all experimental animals. The recorded data were analyzed by using SPSS (version 9.5) statistical package and conception rate, lamb survivability rate were expressed in percentage.

\section{Results and Discussion}

Effects of feeding system on reproductive and productive traits are presented in Tables 1 and 2. 


\subsection{Service per conception and conception rate}

Service per conception in both intensive (1.6) and semi intensive system (1.4) did not show significant $(p>0.05)$ differences. These results are not similar to another finding of Khan [4] who observed that the number of services per conception was 1.29 in Rambouillet ewes which was also lower than the present study. Proper sexual health control and take care of post lambing period will be improved service per conception. The conception rate was higher (98.0\%) in semi-intensive system compare to intensive system (83.0\%). This might have been due to lack of caring during post lambing period and reproductive infection of ewes.

\subsection{Litter size}

Litter size of native sheep reared in both intensive and semi intensive systems of feeding management showed no significant $(p>0.05)$ difference. These results agreed with those obtained by Fahumy [5], Sulieman et al. [6] and Solomon and Gemeda [7]. It is well documented that the litter size improves with advance in age through increased ovulation rate, uterine capacity and maternal traits affecting reproductive efficiency of ewes.

Table 1. Effect of feeding system on reproductive performances of native sheep.

\begin{tabular}{lcccc}
\hline \multicolumn{1}{c}{ Parameters } & Semi-intensive & Intensive & SED & Sign. \\
\hline Service per conception (No.) & 1.4 & 1.6 & 0.16 & NS \\
Conception rate (\%) & 98 & 83 & - & - \\
Litter size (No.) & 1.45 & 1.65 & 0.19 & NS \\
Lambing interval (days) & 263.0 & 258.0 & 4.96 & NS \\
Gestation length (days) & 146.0 & 147.6 & 1.27 & NS \\
Service period (days) & 102.0 & 104.0 & 2.24 & NS \\
\hline
\end{tabular}

\subsection{Lambing interval}

Native sheep of semi-intensive and intensive system of management showed no significant difference in the mean lambing interval (Table 1). Average lambing interval was observed in this trial was so much shorter than many other reports on different genotypes where found longer intervals of 451 and 422 days for $3 / 4$ Ramboullet $x$ 1/4 Chokla and 3/4 Rambouilletx 1/4 Malpura ewes, respectively [8]. The average lambing interval of Kajli ewes was 331.0 days observed by Haque et al. [9]. Considering 60 days as the optimum post lambing oestrus interval, conception of first service and 150 days as gestation length, the optimum lambing interval comes to be around 210 days. The lambing interval consists of service period and the gestation period. Therefore, to minimize the lambing interval, post lambing oestrus interval and service per conception should be minimized. Minimizing lambing interval through dietary intervention and management 
followed in this study, sheep production in the country can be doubled in one and half year.

\subsection{Gestation length}

There was no significant ( $p>0.05$ ) effect of feeding system on gestation length (Table 1 ). Feeding systems are not known to have role in altering the gestation length of a species. Rather it has been shown by many researchers that it is the genotype of the fetus which has crucial role in determining the length of gestation in any species [10].

\subsection{Service period}

Feeding systems had no significant $(p>0.05)$ effect on the service period (from parturition to next conception) (Table 1). The service period was estimated as 102 days under semi-intensive while that of 104 days were found under intensive feeding system. This present result is much lower than other findings. Khan et al. [11] reported that average service period was 250 days. Shinha et al. [12] and Khan [5] found average service periods of 212.1 and 202.3 days in Muzaffarnagri and Suffolk x Muzaffarnagri ewes, respectively. To improve the reproductive efficiency of ewe's service period needs to be reduced.

Table 2. Effect of feeding system on productive performances of Bengal sheep.

\begin{tabular}{|c|c|c|c|c|}
\hline Parameters & $\begin{array}{l}\text { Semi- } \\
\text { intensive }\end{array}$ & Intensive & SED & Sign. \\
\hline Birth weight (kg) & 1.56 & 1.60 & 0.04 & NS \\
\hline $\begin{array}{l}\text { Pre-weaning }(0-3 M) \text { growth } \\
\text { rate }(g / d)\end{array}$ & 65.0 & 71.4 & 6.36 & NS \\
\hline Weaning weight (kg) & 7.3 & 7.7 & 0.36 & NS \\
\hline Milk production (ml/d) & 264.5 & 281.0 & 16.80 & NS \\
\hline $\begin{array}{l}\text { Lamb survivability at birth } \\
\text { (\%) }\end{array}$ & 92 & 100 & - & - \\
\hline $\begin{array}{l}\text { Lamb survivability at } \\
\text { weaned (\%) }\end{array}$ & 93 & 98 & - & - \\
\hline
\end{tabular}

\subsection{Productive performances}

Data on effect of feeding system on birth weight, pre-weaning average body weight, weaning weight and milk production is shown in Table 2. Birth weight and average preweaning weight gain were not significantly different $(p<0.05)$ in semi-intensive and intensive feeding systems. Similar results were reported by Dickson et al. [13] in West African ewes and Macedo and Hummel [14] in Pelibuey ewes. The average pre-weaning 
growth rate was not significantly $(p>0.05)$ higher $(71.4 \mathrm{~g} / \mathrm{d})$ compared to semi-intensive feeding system $(65.0 \mathrm{~g} / \mathrm{d})$. The mean weight at weaning was recorded $7.3 \mathrm{~kg}$ and $7.7 \mathrm{~kg}$, respectively for semi-intensive and intensive management system. Different weaning weights have been reported $8.41 \mathrm{~kg}$ at 105 days [15]); $9.5 \mathrm{~kg}$ for weaning at 105 days [16]) and $12.7 \mathrm{~kg}$ at 90-120 days [17]. Average milk yield was not significantly ( $p>0.05)$ higher $(264.5 \mathrm{~g} / \mathrm{d})$ in intensive system than semi-intensive feeding system $(281.0 \mathrm{~g} / \mathrm{d})$.

\subsection{Lamb survivability and conception rate}

Lamb survivability at birth was higher (100\%) in intensive system than semi-intensive system (92.0\%). The survivability at weaning period was found to be higher $(98.0 \%)$ in intensive system than semi-intensive (93.0\%) system. The excellent survival rates observed for intensive feeding system compared to semi-intensive system. Better performance of lamb in respect to survival rates in intensive system was attributable to intensive health care and husbandry practices during birth and also at weaning.

On the other hand, conception rate was found to be better in semi-intensive feeding system (98\%) than that of intensive system (83\%). Higher conception rate of sheep under semi-intensive system of management might be due to regular exercise of sheep as because they were maintained under some parts of intensive and some parts of extensive system of management. Other factors might have some positive roles in enhancing the conception rate in semi-intensive system of management.

\section{Conclusion}

Reproductive and productive traits were not significantly affected by the system of rearing, i.e. intensive and semi-intensive feeding system. Conception rate was higher in semi-intensive system than intensive system. On the other hand lamb survivability was higher in intensive system than semi-intensive system. It may be concluded that semiintensive feeding system is better to rear sheep under commercial purpose compared to intensive feeding system. Since this study did not focus on farmer's socioeconomic conditions, further study would be required to assess its net economic returns with respect to farmer's conditions.

\section{References}

1. Bangladesh Economic Reviews (BER), Government of the People's Republic of Bangladesh, Finance Division, Ministry of Finance 92 (2008).

2. S. W. Kochapakdee, S. Pralomkarn, S. Saithanoo, A. Lawpetchara, and B. W. Norton, Australasian J. Anim. Sci. 7, 289 (1994).

3. J. M. Mahajan, D. S. Chauham, and V. P. S. Tomar, Indian J. Anim. Res. 10, 90 (1976).

4. W. M. Khan, M. Sc. Thesis, College of Vet. Science Lahore, University of Agriculture, Faisalabad (1989).

5. M. H. Fahumy, Small Ruminant Res. 2, 253 (1990). http://dx.doi.org/10.1016/0921-4488(89)90005-9 
6. A. H. Sulieman, A. R. Sayers, and R. T. Wilson, ILCA Research Report No. 18, International Livestock Research Centre for Africa (Addis Ababa, Ethiopia, 1990).

7. A. Solomon and D. Gemeda, Bako Agricultural Research Report. International Livestock Research Centre (ILRC) for Africa (Addis Ababa, Ethiopia, 2000).

8. K. Kishore, D. Gour, P. S. Rawat, and R. C. Malik, Indian J. Anim. Sci. 52, 1108 (1982).

9. A. Haque, C. S. Ali, N. Ahmad, H. A. Samad, and Z. I. Qureshi, Sarhad J. Agric. 4, 241 (1988).

10. G. E. Bradforad, R. Hart, J. F. Quirke, and R. B. Land, J. Repord. Fert. 30, 459 (1972). http://dx.doi.org/10.1530/jrf.0.0300459

11. M. D. Khan, N. Ahamad, H. A. Samad, and N. U. Rehman, Intern. J. Agric. Biol. 2, 4 (2000).

12. N. K. Sinha, J. D. Joshi, and K. L. Sahni, Indian J. Anim. Sci. 49, 1096 (1979).

13. L. Dickson, G. Torres, R. D’Aubeterre, and O. Garcia, Revista de la Facultad de Agronomía (LUZ) 21 (1), 59 (2004).

14. R. Macedo and J. D. Hummel, Livestock Res. Rural Dev. 18 (6), article 77 (June, 2006).

15. J. C. London and J. H. Weniger, J. Anim. Breed. Genetics 112, 431 (1996). http://dx.doi.org/10.1111/j.1439-0388.1995.tb00582.x

16. C. V. Yapi-Gnaoré, A. Oya, J. E. O. Rege, and B. Dagnogo, Anim. Sci. 64, 291 (1997). http://dx.doi.org/10.1017/S1357729800015861

17. J. P. Poivey, J. Charray and J. M. Hubert, World Rev. Anim. Prod. 22, 77 (1986). 